\title{
PIECES OF A PUZZLE \\ (A CONCISE MONETARY HISTORY OF THE 2008 HUNGARIAN FINANCIAL CRISIS)
}

\author{
Júlia KIRÁLY
}

In 2008, Hungary was heavily hit by the global financial crisis, and had to turn to the IMF among the first. The paper analyses the road leading to the post-Lehman liquidity crisis from the point of view of Magyar Nemzeti Bank (MNB), the central bank of Hungary. Based on the minutes and the press releases* of the Monetary Council (MC), a comprehensive account is given why the puzzle was put together too late.

Keywords: global financial crisis, decoupling, inflation targeting, monetary policy, MPC, communication, Hungary

JEL classification indices: B26, E5, F32, G01, G18, G21

* Press releases are immediately published after the MC meetings, while the more detailed Minutes of the Meetings, which include the individual opinions of the members, are published two weeks later.

Júlia Király, Professor at the International Business School Budapest and Economic Research Institute of the Hungarian Academy of Sciences. Between 2007-2013, she was the Deputy Governor of MNB, the central bank of Hungary. 
At the beginning of the 2000s, Hungary left the sustainable growth path, and the "fiscal alcoholism" (Kopits 1998) of the government led to the accumulation of internal and external imbalances. In 2001, the Magyar Nemzeti Bank (MNB), the central bank of Hungary adopted flexible inflation targeting (IT) as a monetary policy framework, which presumed smooth cooperation between the central bank and the government. In the presence of increasing fiscal imbalance threatened with fiscal dominance, it became increasingly harder for the Monetary Council (MC) to look through the superposed fiscal shocks. The result was the worst combination of loose fiscal and tight monetary policies. In the wake of the crisis, monetary policy was still struggling to achieve the 3 per cent inflationary target. Debates in the MC focused on the possible explanation of the permanent failure of achieving this goal and on the search for a suitable monetary strategy. In this framework of thinking, less attention was paid to the possible contagion effect of the subprime crisis emanating from the United States housing market.

In Section 1, the dilemmas of inflation targeting are discussed. Section 2 surveys the MC's activity under the clouds of the subprime cycle. In Section 3, the brutal consequences of the Lehman-bankruptcy are outlined, and the measures taken by the Hungarian policymakers are surveyed. In Section 4, I try to put together the pieces of the puzzle and draw the lessons for the future.

\section{DESPERATE FIGHT TO ACHIEVE THE INFLATION TARGET}

By the mid-2000s, all EU member Central and Eastern European (CEE) countries, which adapted the IT framework, were able to bring down inflation and keep it on the target, except Hungary, which managed to bring down the double digit inflation, but then missed the target either from below or from above (Figure 1). The recurring question was the same: whether the actual and the forecasted price increase was only a "one off" and the MC should look through it, or it will push up inflationary expectations, and thus the central bank should intervene to anchor the expectations. The MC had to decide whether an intervention would really help to achieve the target or it is a useless sacrifice, which would only further curb GDP growth which was meagre anyway.

First, there was a hot debate on the overall effect of the consolidation program of the re-elected Social-Liberal coalition government. On $10^{\text {th }}$ of June 2006 after winning, the re-elected Prime Minister admitted that the actual deficit was much higher than the earlier forecast, and without intervention it would reach 10 per cent of GDP by the end of the year. Thus, a consolidation program was announced, which promised to reduce the deficit to 3.5 per cent in two years, with the help of austerity measures totalling to 1000 billion HUF ( 4 billion $€$ ). The so- 


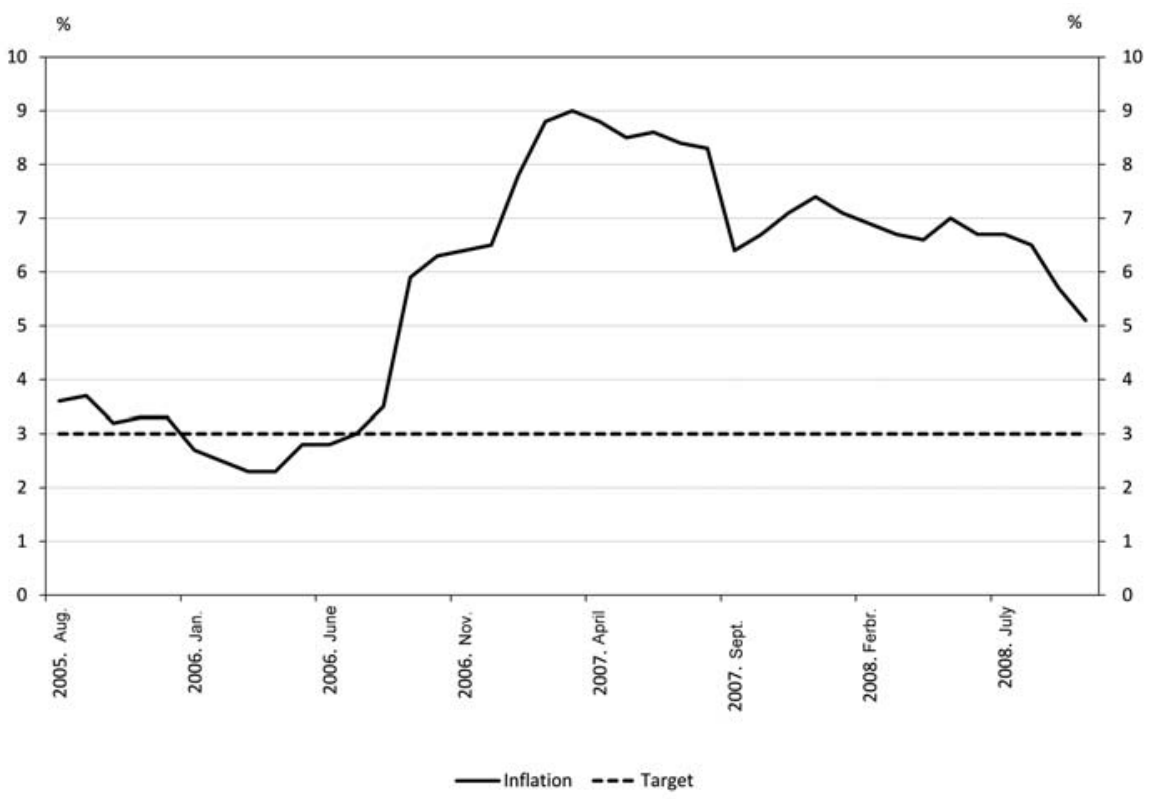

Figure 1. Inflation and its target in Hungary (2005-2008)

Source: MNB Statistical series.

called "Gyurcsány-package" - named after the Prime Minister ${ }^{1}$ - was questioned within the MC.

Several members pointed out that the program first of all increased the government revenues, and the expected tax measures (VAT, social security contribution, etc.) would heavily push up inflation. Other members asserted that within two years the program would significantly curb the internal demand, and as a consequence the inflation as well, so the MC should not tighten the monetary conditions. These members identified a different channel of disinflation: the consolidation mitigated the vulnerability and decreased the risk spread in the country. This debate slowly faded away during the second year of the consolidation when disinflationary effects strengthened.

Second, not independently from the debate described above, the MC could not agree on the evaluation of the output gap. According to the staff analysis in 2007, the earlier positive output gap became negative due to the consolidation package, but in 2008 the negative gap was quickly diminishing (Figure 2). Some mem-

Mr. Ferenc Gyurcsány was Hungary's Prime Minister between 29 September, 2004 and 14 April, 2009. 
bers stressed that while the gap is negative a rate-hike is really counterproductive, while others pointed at the closing output gap and the high inflationary expectations. When after several years the staff re-measured the output gap, it turned out that it had been positive even during the consolidation, and so the disinflationary effect was very weak. Measuring potential output, output gap or capacity gap is not a simple technical issue. Though during the years techniques have been evolving, there isn't a reassuring "final solution". Re-estimations often find that earlier estimations were not correct (Giorno et al. 1995; ECB 2005) as happened in the case of the MNB.

While the MC tried to assess the evolution of the output gap, a very important pervasive effect of tightening through the credit channel was left out of consid-
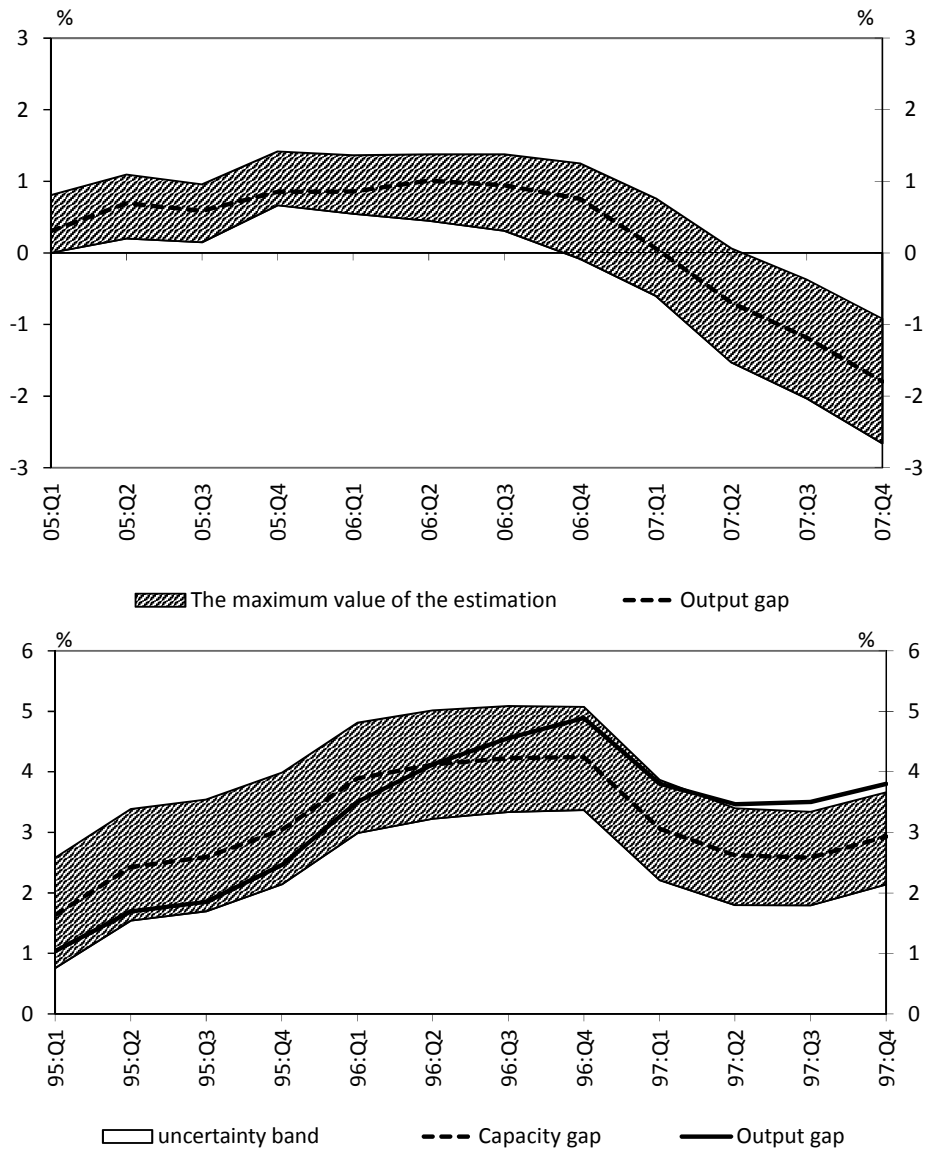

Figure 2. Output gap 2005-2007 (as measured in 2008 and in 2012)

Source: MNB Inflation Reports 2008 May and 2012 June. 
eration. Due to the fact that both the households and the SMEs were borrowing in FX (particularly in CHF), an increase in the HUF rates resulted in the increase of FX loans, which stimulated the internal demand instead of curbing it as was nicely proved 10 years later by Ongena et al. (2017).

Thirdly, another hot topic was the labour market, especially the increasing unit cost of labour, and the steadily high 8-9 per cent increase in annual nominal wage. According to the staff, the expectation of high inflation by the trade unions and the permanent increase of minimal wage pushed up the inflation. The MC could not get a clear picture since certain austerity measures contributed to the so called "whitening" of the labour market (i.e. reducing tax evasion), and again, it was very hard to clean the trend from the "one offs".

Fourthly, the hike in the price of the crude oil and other raw materials seemed to be supply driven and long-lasting. In the summer of 2008, at the peak of the price hike, several studies concluded that due to the increased supply cost the world should learn to live together with a 90-100 USD/barrel oil price. Others argued that biofuel production was responsible for the increased food prices (Mueller et al. 2011), and last but not least that the iPhone-mania would keep the prices high for all the rare metals used for production (Figure 3). Inflation due

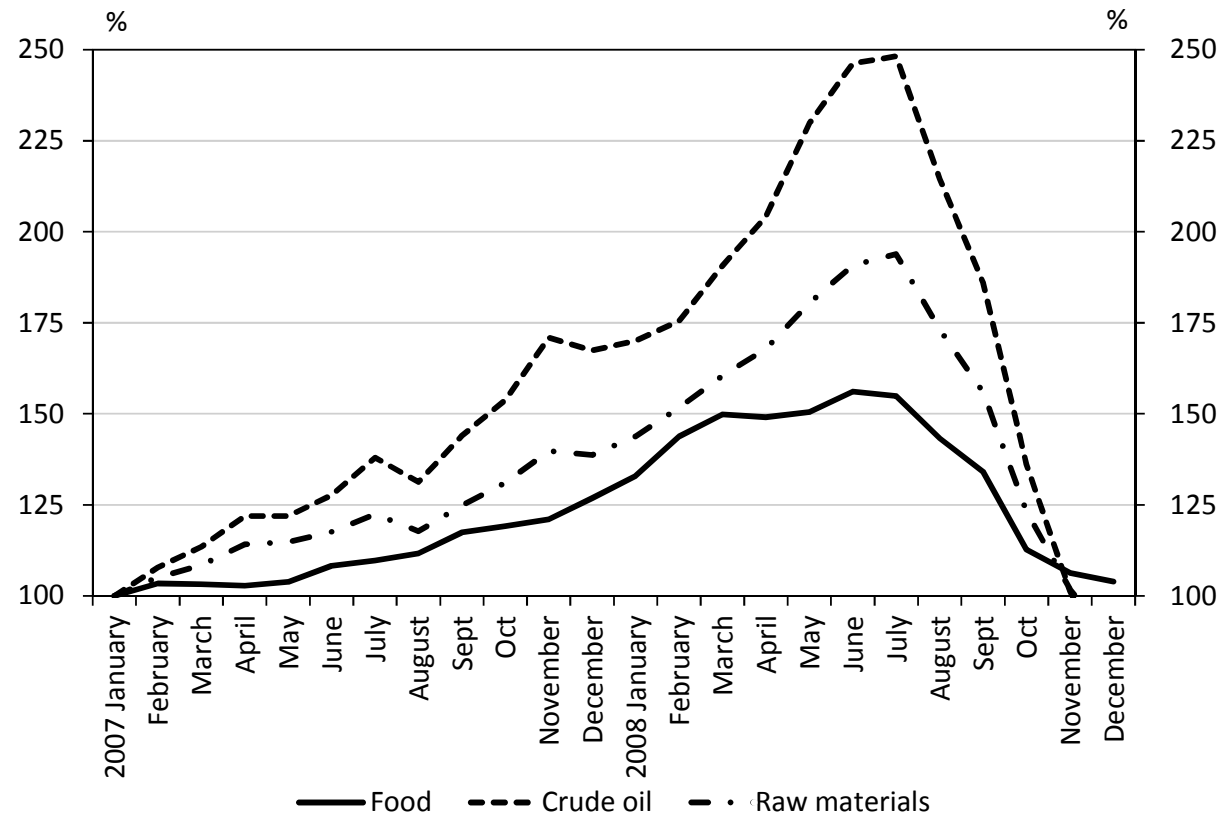

Figure 3. Raw material price hike (January $2007=100 \%$ )

Source: MNB Inflation Report 2009 February. 
to the permanent hike was expected to get out of control, so even the European Central Bank (ECB) increased its base rate in July $2008 .{ }^{2}$ Nobody could imagine that in half a year all these prices will be halved due to the Great Recession.

To better understand the debates and the different standpoints we should not forget that during the first six years of the IT regime, the target was always missed, so the credibility of the MC was at stake. Several members, especially the newly nominated leaders of the bank (the Governor and the two Deputy Governors) were eager to build the credibility of the central bank, and therefore they were ready to be a little bit more hawkish than necessary.

Finally, the wide band of the HUF exchange rate was also a recurrent topic of the MC. After six years of crawling peg with a narrow band, when the IT was adapted, the final decision was not to demolish the band but apply a wide band +/- 15 per cent around the mid-rate. As a consequence, the HUF was not free floating as in the neighbouring countries, and due to the tight monetary conditions the HUF was always close to the strong end of the band. The market participants had "learned" that the exchange rate is "fixed" somewhere around $250 \mathrm{HUF} / €$. In March 2008, the MC almost unanimously greeted that a new agreement between the MNB and the government was achieved, the band was abolished, and the HUF was free floating. From April 2008, the HUF had been gradually appreciating, and in July it achieved its peak at $228 \mathrm{HUF} / €$. Both politicians and exporters started to campaign against the "ultra-strong" Hungarian currency. It was difficult to explain that the real appreciation had never been lower, but earlier it was due to the high inflation.

All in all, monetary policy debates in 2006-2008 focused on the desperate fight for achieving the 3 per cent inflation target under deteriorating economic environment. In the period from the start of the government consolidation program (2006 June) till the outbreak of the post-Lehman liquidity crisis (2008 October), the MC's decisions about the base rate reflected this uncertainty. With the benefit of hindsight, a kind of "stop-go" cycle can be detected: rough tightening and then timid loosening of monetary conditions (Figure 4).

\section{UNDER THE CLOUD OF THE CRISIS}

While the MC was occupied with achieving the inflation target, the American subprime crisis evoked smaller and larger turbulences all over the world. In Europe, the first signals of the contagion already appeared in the summer of 2007.

2 On $9^{\text {th }}$ July 2008 , the base rate increased from $3.00 \%$ to $3.25 \%$. It was the top of the interest rate cycle. 


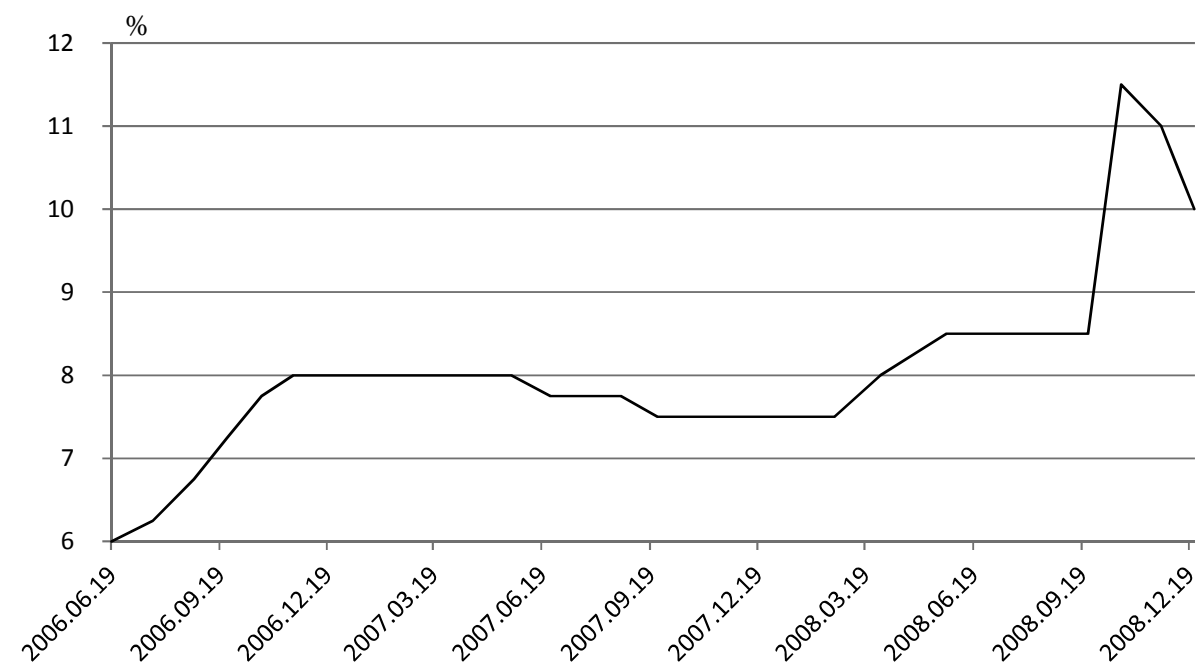

Figure 4. MNB Base rate, 2006-2008

Source: MNB Statistical series.

On $9^{\text {th }}$ August, BNP Paribas announced the suspension of two of its CDO (collaterized debt obligation) funds. Markets reacted hysterically, overnight rates rocketed. The ECB had to intervene providing 95 billion $€$ fresh liquidity at fixed rate open-end tender (Papadia - Valimaki 2018). The liquidity crisis was shortly over, but liquidity on money markets was steadily declining, credit default swap (CDS) spreads of banks was steadily increasing, and all costs of funding started to increase. Financial stability was at stake. More and more European banks admitted its exposure to the so called toxic assets, such as CDOs, squared CDOs, etc.

In the MNB, the first alarm-bell memo was prepared by the staff in the summer of 2007: "From among the risk factors, the high-risk American mortgage loan market continues to exert a negative impact on the investment sentiment. The bankruptcy of certain investment funds and the announcements by large credit rating agencies about assigning or the prospect of assigning lower credit ratings to mortgage loan products resulted in the increase of credit premium in other market segments as well. In addition to corporate lending the premium of sovereign debts rose slightly as well. In spite of the increase of credit premium the developments on the American mortgage market will probably exert only a marginal impact on risk appetite until affecting other markets or household consumption as well of which there is no indication as yet." ${ }^{3}$ The general feeling

Minutes of the MC Meeting on 23 $3^{\text {rd }}$ July 2007: 4. 
was that these turbulences will exert only "marginal impact"; most of the central banks hoped "soft landing", too.

This cautious optimism was in line with the thinking of outstanding central bankers of the world. In 2007, Ben Bernanke, the Chairman of the FED felt that "All that said, given the fundamental factors in place that should support the demand for housing, we believe the effect of the troubles in the subprime sector on the broader housing market will likely be limited, and we do not expect significant spillovers from the subprime market to the rest of the economy or to the financial system" (Bernanke 17 May 2017: 7). As far as the emerging markets were concerned, optimism was even higher at that time. As the Governor of the Central Bank of Mexico, Guillermo Ortiz formulated in an often cited quote: "This time we did not cause it" (Blinder 2013: 171), consequently, this crisis would fundamentally be different from the "peso-crisis" in 1995, or the "Eastern Tigers crisis" in 1997, or the Russian-crisis in 1998, all of which had started in the emerging markets and the contagion effect had shaken the world economy. In 2007, the then popular "decoupling" theories assumed that this time the crisis stemmed from the most developed financial markets, so the emerging markets would be less contaminated and would suffer less. A paper published in 2009, but written much earlier - Dooley and Hutchison (2009) - analysed 16 emerging markets including Hungary with event-driven econometrics and confirmed our assumptions that the emerging markets were indeed enjoying a certain heyday till the Lehman crisis. Most of the currencies appreciated against the USD, and bank crises had avoided these countries, since their banks (even the mother banks of the local banks) had not accumulated significant stock of toxic assets.

The MC has not assumed that the turmoil would not affect the Hungarian markets at all, since the increase of the cost of foreign funds and the shortening of the maturities were immediate signals of the coming turbulent times. Nevertheless, members were optimistic: "The financial market turbulence stemming from the problems in the US sub-prime mortgage market has contributed significantly to uncertainty in the global investment environment, leading to a rise in the required risk premium on forint assets. However, the Council believes that the imbalances in the domestic economy have recently diminished considerably. This, in turn, has reduced Hungary's vulnerability to external shocks" ${ }^{4}$

In August 2007, the MC discussed a report about a European-wide crisis simulation exercise in which the MNB participated, as well. The calculations suggested that in case of a liquidity crisis, the MNB has the necessary toolkit at hand for a prompt intervention. However, either the crisis simulation or the staff report summarizing the conclusions of the report did not consider the possibility of a FX

$4 \quad$ Press Release of the MC, $27^{\text {th }}$ August 2007. 
liquidity crisis. Vaporizing FX liquidity was not assumed in any of the stress test scenarios. None of the central banks had run liquidity stress test with non-functioning money markets. It was unconceivable that any of the liquid money markets, in particular, the super-liquid FX swap market could dry out. ${ }^{5}$ Consequently, neither the staff nor the $\mathrm{MC}$ connected the contagion of the subprime crisis with the booming FX lending; nobody envisaged a FX liquidity crisis.

In September 2007, two MC members warned about the recent disturbances on the international financial markets, the "effects of which on the financial markets and the economy were not yet well understood, and therefore, the ultimate impact was also unclear." These two members (Ms. Ilona Hardy and the present author) voted against the majority, i.e. against a further decrease of the interest rates by 25 basis points. This was the last decrease before the liquidity crisis hit the country. In October 2007, the loosening cycle was stopped due to the "upside risks to inflation and uncertainty surrounding the global investment climate". Nevertheless, majority of the council was hopeful, trusting in the decoupling and the decreasing vulnerability of the country: "The financial market environment remained supportive, despite the problems arising from the US mortgage market showing virtually no sign of easing over recent months. Demand increased for risky assets which were not affected directly by the turmoil. Currencies and stock market indices of several emerging countries rose to historical highs in early October, and risk premia fell." " Similar optimistic feeling prevailed in all other CEE central banks.

However, the CDS spreads started slowly crawling up (Figure 5), reflecting that "in financial markets, investor sentiment deteriorated strongly", and "due to the continued repricing of risks, credit spreads and risk premia on emerging market debt once again rose back to, and slightly above, levels experienced during the sell-off in August"'.

In January 2008, the MC, as usually, revised its international reserve strategy, and concluded that according to the statistical data at hand ${ }^{9}$ the reserves were satisfactory by all indicators. At that time the so-called Greenspan - Guidotti rule was the most widely-used standard of adequacy for emerging markets. According to this rule of thumb (Greenspan 1999), international reserves should cover short term debt maturing in 12 months. Clearly the cut-off at 12 months is essentially arbitrary, driven mostly by the definition of short-term debt itself.

5 In Hungary, the daily turnover of the FX swap market was about 750 bn HUF ( 3 bn EUR) while that of the FX spot market was all in all 250 bn HUF (1 bn EUR).

Press release of the MC, $29^{\text {th }}$ October 207.

Minutes of the MC Meeting on 29 ${ }^{\text {th }}$ October 2007: 2.

Minutes of the MC Meeting on $26^{\text {th }}$ November 2007.

Since 2007, the Hungarian Statistical Office revised the data several times. 


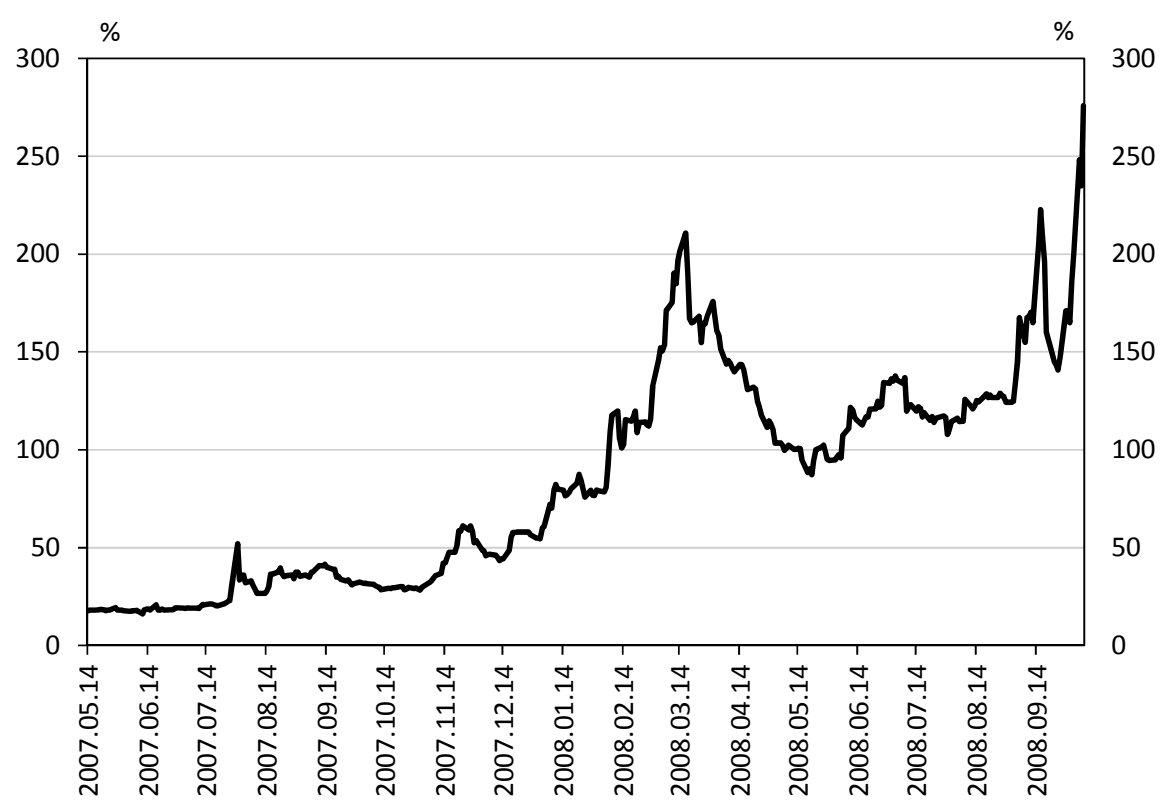

Figure 5. Five-year CDS spread of Hungary (2007-2008)

Source: MNB Inflation Reports November 2007, February 2009.

At the beginning of 2008, the Hungarian Greenspan - Guidotti ratio was above 100 per cent, however, due to the rapid shortening of the foreign debt and the market turbulence, the $\mathrm{MC}$ decided to stop converting incoming EU funds on the market in order to increase the bank's international reserves. ${ }^{10}$ To increase the reserves further, the MC urged the Government Debt Management Agency (AKK) in several letters to issue FX denominated bonds. Unfortunately, the AKK missed the right market moment, in 2007 it issued only 300 billion HUF (1.2 bn $€)$ instead of the planned 500 billion, ( 2 bn $€$ ), and in 2008 failed to issue bonds, at all (MNB 2008). All in all, reserves did not increase, though, at least, did not decrease either. Reserves seemed to be adequate, especially because a large part of the short term debt was provided by the foreign mother banks, and in peaceful times analysts did not consider it as "hot money".

10 This decision has been reversed in March 2009, when during the CEE region turbulence the $\mathrm{MC}$ announced to start to convert the EU funds on the market in order to stop the sharp depreciation of the forint. At that time reserves were twice as large as in 2008 due to the 20 billion EUR IMF-EU package. 
In March 2008, the first direct contagion effect reached the Hungarian money markets. Liquidity seemed to disappear from the government bond market, bidask spreads increased and other liquidity indicators deteriorated, too. The turbulence was partly due to an almost forgotten element of the 2006 "Gyurcsánypackage": pension funds were actually obliged to decrease in their portfolio the share of the government papers and increase the share of stocks. This regulation, adopted just before the subprime crisis, resulted in the forced outflow of government papers from the pension funds, which in "due time" caused the March turbulence.

Intervention by the Debt Management Agency and a rapid hike of the base rate by 50 basis points by the MC calmed the markets, and the focus of the MC soon shifted back to the raw material price hike: "For most of May, pressures on global markets caused by turbulence in the US sub-prime market were abating. By contrast, international capital market developments have been dominated by rises in inflation expectations over the past few weeks. Although there has been a significant easing in world food prices since March, the rise in oil prices has continued uninterrupted, and trend inflation rates for May again caused negative surprises in a number of countries. Some observers argue that recent oil price rises have been driven by fundamental factors (supply has been slow to adjust, and the decline in demand has been hampered by government subsidies), and therefore, there is little prospect of a fall in prices. Until recently, the world's major central banks have focused on the downside risks to growth, but both the $E C B$ and the Fed have now been placing greater emphasis on inflation in their communications. As a result, expectations of official interest rates in the euro area and the US have increased."11

In June 2008, a Stability Roundtable was organized by the MNB with the participation of $10 \mathrm{CEE}$ central banks. The conclusion was unanimous: "The participants of the meeting stated that the financial turmoil generated by the US subprime crisis affected only indirectly the banking systems of the Central and Eastern European region, and the shock-absorbing capacity of the financial institutions proved to be sufficient. Funding liquidity risks, effects on the lending activity, and cross-border co-operation among authorities enhancing financial stability will stay in the center of attention." ${ }^{2}$ The message was clear: the CEE region is not vulnerable and will not significantly suffer from the subprime crisis.

$11 \quad$ Minutes of the MC Meeting on $23^{\text {rd }}$ June 2008.

$12 \mathrm{http}: / /$ www.mnb.hu/sajtoszoba/sajtokozlemenyek/2008-evi-sajtokozlemenyek/sajtokozlemenya-kozponti-banki-penzugyi-stabilitasi-kerekasztalrol 


\section{THE LEHMAN TSUNAMI}

On $15^{\text {th }}$ September 2008, the Lehman Brothers, the $4^{\text {th }}$ largest US investment bank collapsed. During the following days nothing special happened on the emerging markets. What's more, evaluation of the CEE region improved, the CKZ and the PLZ appreciated, and the Polish Central Bank had announced that Poland would join the Eurozone in 2011. On the Lehman-week most of the analysts stayed within the decoupling scenario for the emerging markets.

The weekly staff analysis of the MNB recurrently stated that some kind of contagion could occur in our region, but there was no sign of a brutal crisis.

On $29^{\text {th }}$ September 2008, the US Congress refused the 700 billion USD large Troubled Assets Relief Program (TARP) (Bernanke 2016). Though five days later the bill was passed after all, but it was too late - the Lehman-tsunami swept over the world's financial markets. During two weeks after the Congress's refusal, CDS spreads and interest rates rocketed, while stock prices plunged not only in the US markets, or in the developed countries, but this time in the emerging markets as well. There was no decoupling. Financial markets, including the superliquid money markets dried out.

On the very same day, $29^{\text {th }}$ September at the rate setting session of the MC, the members expressed their mild worries only: "Although Hungary was no longer among the most vulnerable countries, forint investments were not the safest assets for investors and, therefore, a potential worsening of financial disruptions might have a more pronounced effect on the prices of forint assets compared with other countries of the region." ${ }^{13}$ Nevertheless, the MC did not see any reason for any kind of monetary intervention.

At the beginning of October, some domestic banks reported serious frictions on the FX swap market, yet, the big picture of the central bank was rather optimistic. According to the staff, Hungary was hardly affected by the Lehmancrisis, the HUF had only slightly depreciated. In their view, on the one hand the improvement of the budget in the past two years mitigated the external financing needs of the country, on the other hand, the whole CEE region was positively judged. The decline of the global risk appetite was not followed by capital flight from the emerging markets, especially, because the risk spread of the advanced economies increased, as well.

In October, however, the tsunami hit Europe: in the first week the share prices of the big European banks plunged, their CDS spread almost exceeded those of the big American banks. The Irish banking sector collapsed, all the three big Irish

$13 \quad$ Minutes of the MC on 29th September 2008. 
commercial banks had to be nationalized. The Irish government announced unlimited deposit insurance, and in a few days most of the European countries were forced to follow the Irish example to protect the banks deposit base.

\section{A few horrible days}

On $8^{\text {th }}$ October (Wednesday), Hungary also announced the unlimited government guarantee. The heads of the Ministry of Finance, the MNB and the Financial Supervisory Authority (PSZAF) issued a triparty press release greeting the ECOFIN initiative about a joint standpoint with respect to the financial crisis, and declared that the deposit of the Hungarian citizens are safe. Mr. András Simor, the Governor of the Central Bank added in the form of a verbal intervention: "The Hungarian banking sector is strong, its capital base and profitability are high by European standards, the HUF and FX liquidity of the banks is adequate. Though the funding conditions deteriorated, but the foreign owners mitigate this negative effect. There are a lot of irrational elements in the actual market crisis. Our financial sector is deeply integrated in the European financial market, but we are affected only indirectly. The market liquidity may further deteriorate, and the real economy may slow down. The Central Bank keeps a close watch on the financial markets and the functioning of the banks and would intervene if necessary." 14 These last words became famous and often quoted later on, but these words were not his words. Mr. Simor merely repeated the main message of the Stability Report of the MNB. The report was published and accepted by the $\mathrm{MC}$ on the same day.

The capital base of the Hungarian bank was really strong; none of the domestic banks went bankrupt during the crisis. The mother banks proved to be responsible owners, provided their subsidiaries with the necessary capital and funding in due time. But there was a dramatic and unprecedented shock for a very short time. On $8^{\text {th }}$ October, the Hungarian money markets were still "smoothly" functioning. The usual banality can explain the blindness of the MC: "There was no storm yet one day before the storm." The message of the Stability Report mirrored that the MC was operating in a "vacuum of information": the daily data gave a more or less true picture about the business day already closed, while they did not help to form reliable forecasts about business conditions of the following day. The MC overestimated the positive effect of the budget consolidation on the vulnerability of Hungary and underestimated the strength and consequences of the Lehman-tsunami.

14 https://www.portfolio.hu/gazdasag/korlatlan-garancia-magyar-betetekre-is.103767.html 
On the next day, $9^{\text {th }}$ of October (Thursday) the Hungarian money markets entirely dried up:

- market makers and price quotations disappeared from the government bond market;

- the regular T-Bill auction of the AKK failed;

- trade on the Stock Exchange had to be suspended due to harsh price drop;

- the share price of the OTP Bank, by far the largest Hungarian commercial bank, collapsed;

- HUF was under strong depreciation pressure;

- FX swap market froze;

- there was no FX liquidity provider, the Hungarian banks could not roll over the expiring swaps, which funded their FX denominated loans.

The country's leaders (the Prime Minister, the Minister of Finance, the Governor of the central bank and the head of the Supervision Authority) faced the following challenges:

- market confidence should be restored;

- the menacing state default should be avoided;

- the government bond market should be revitalized;

- the banking sector should be provided with fresh FX funds;

- the sharp depreciation of the HUF should be stopped;

- the FX reserve of the Central Bank should be replenished.

It was really the sinister sudden stop, when funding suddenly disappears from the system. On $10^{\text {th }}$ October (Friday), the headlines of the foreign newspapers suggested that Hungary would be "the second Iceland", journalists and analysts all envisioned bank-, exchange rate-, balance of payment- and fiscal-crisis. It seemed to be a unanimous view that the FX reserves of the MNB would not be enough to cover the diminishing funding needs. Though reserves still were above 100 per cent of the short term debt, but due to the crisis they were thought to fall below this ratio very, very soon. Analysts - like the hungry tigers - immediately jumped on the country.

In order to restore market confidence, to avoid the state bankruptcy and to replenish international reserves, Hungary turned to the IMF and the European Commission. The first measure to restore the liquidity of the interbank FX market was announced on the first night. On $10^{\text {th }}$ October, the central bank stepped in the overnight swap market as an intermediary. On the one side, those banks, which provided FX liquidity could make business with the MNB, while on the other 
side, the MNB provided FX liquidity for the "thirsty" domestic banks. These were the so called "bilateral swap tenders". ${ }^{15}$

On $10^{\text {th }}$ October, the MNB sent a letter to the ECB asking for a EUR-HUF swap line. These kinds of swap lines had already been set up among the major central banks (Bank of England, Swiss Bank, Fed, ECB, Bank of Japan) and then smaller central banks outside the Eurozone could apply for it as well (Papadia - Valimaki 2018): the ECB set up swap lines with the Danish and the Swedish Central Bank, however, declined the request of the Hungarian and the Polish central banks. Instead, the ECB offered a repo line, which meant that the MNB had access to euro liquidity at the expense of the diminishing international reserves. Nevertheless, under the given circumstances, the MNB had to accept the offer, and using the ECB repo-line from $16^{\text {th }}$ October could provide overnight and two-week EUR swap to the market. Fortunately, the mother banks behaved in a much more responsible way than the ECB, and till the end of the year increased their funding in their local banks by more than 20 per cent helping to substitute the vanished market funds. So, the mother banks and the MNB together could revitalize the Hungarian FX money markets, and provide sufficient FX liquidity for the banks.

On $12^{\text {th }}$ October, a joint EU-IMF mission arrived in Budapest. The forthcoming, two-week long negotiations with the Hungarian authorities run day and night in order to get a clear common picture about the economy and to agree about all those measures that should be taken by the country to get back on the sustainable growth path.

The government bond market was frozen, too. The MC decided that in spite of the famous Article 123 of the Lisbon Treaty ${ }^{16}$, the MNB should enter the secondary market. The MNB invited the primary dealers $\left(16^{\text {th }}\right.$ October) and the fund

$15 \mathrm{http}: / /$ www.mnb.hu/en/pressroom/press-releases/press-releases-2008/the-mnb-s-o-n-fxswap-standing-facility-providing-euro

16 Article 123, Paragraph 1: Overdraft facilities or any other type of credit facility with the European Central Bank (ECB) or with the central banks of the Member States (hereinafter referred to as 'national central banks') in favour of Union institutions, bodies, offices or agencies, central governments, regional, local or other public authorities, other bodies governed by public law, or public undertakings of Member States shall be prohibited, as shall the purchase directly from them by the ECB or national central banks of debt instruments. Paragraph 2: Paragraph 1 shall not apply to publicly owned credit institutions which, in the context of the supply of reserves by central banks, shall be given the same treatment by national central banks and the ECB as private credit institutions. http://www.lisbon-treaty.org/wcm/the-lisbon-treaty/ treaty-on-the-functioning-of-the-european-union-and-comments/part-3-union-policies-andinternal-actions/title-viii-economic-and-monetary-policy/chapter-1-economic-policy/391article-123.html 
managers $\left(17^{\text {th }}\right.$ October) for a cordial brainstorming, and at the end of the day a joint agreement was accepted. The primary dealers and the fund managers agreed to re-enter the market and buy government bonds, while on the other hand, the central bank committed itself to buy the same amount on the secondary market $^{17}$. In addition, the MC decided about two new loan facilities (2-week and 6-month instruments) to finance the market participants, who were willing to sign the agreement. ${ }^{18}$ The action proved to be very successful and soon the T-Bond market became liquid, again.

After $9^{\text {th }}$ October the turbulent FX market could not calm. The IMF agreement has not yet been finalized, when the MC was alerted that serious short positions had been built up against the HUF. Since the market was extremely volatile, and banks were afraid even of a possible bank-run, on $22^{\text {nd }}$ October an extraordinary $\mathrm{MC}$ meeting decided to raise the base rate by 300 basis points, to 11.5 per cent, the second highest in Europe at that time. This brutal action made the shortening of the HUF much more expensive, and the market calmed down. It was a really difficult decision: while interest rates were decreased by the central banks all over the world because of the approaching recession, some vulnerable countries (Iceland, Hungary and then the Ukraine) had to raise their base rates to avoid deeper financial crisis. When the markets calmed down, the MC lowered interest rates as fast as possible. During the 2009 recession, the rates almost halved, in May 2010 the base rate was already historically low at 5.25 per cent, expressing the risk spread of Hungary (180 basis points at that time).

On $26^{\text {th }}$ October (Sunday) evening, after a hard two-week long negotiation, the agreement was achieved with the international institutions, the Letter of Intent including the agreed measures to be taken by the Government had been prepared and accepted by all the negotiating parties. As Strauss-Kahn asserted: "An IMF staff mission and the Hungarian authorities, in close consultation with the EU, have reached broad agreement on a set of policies that will bolster the Hungarian economy's near-term stability and improve its long-term growth potential. The authorities' program will ensure fiscal sustainability and strengthen the financial sector. A substantial financing package in support of these strong policies will be announced when the program is finalized in the next few days. Participants will include the IMF, the EU, and some individual European governments, together with regional and other multilateral institutions. With Hungary's commitment to

$17 \mathrm{http} / /$ www.mnb.hu/en/pressroom/press-releases/press-releases-2008/notice-on-the-mnbs-auctions-for-the-purchase-of-government-securities / http://www.mnb.hu/en/pressroom/ press-releases/press-releases-2008/press-release-on-the-agreement-between-the-magyarnemzeti-bank-and-the-primary-government-security-dealers

$18 \mathrm{http} / /$ www.mnb.hu/en/pressroom/press-releases/press-releases-2008/terms-and-conditionsof-the-mnb-s-new-collateralised-lending-facilities 


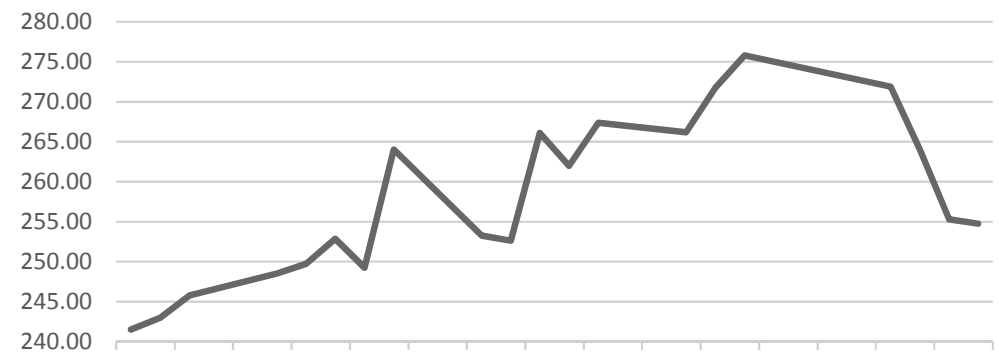

240.00
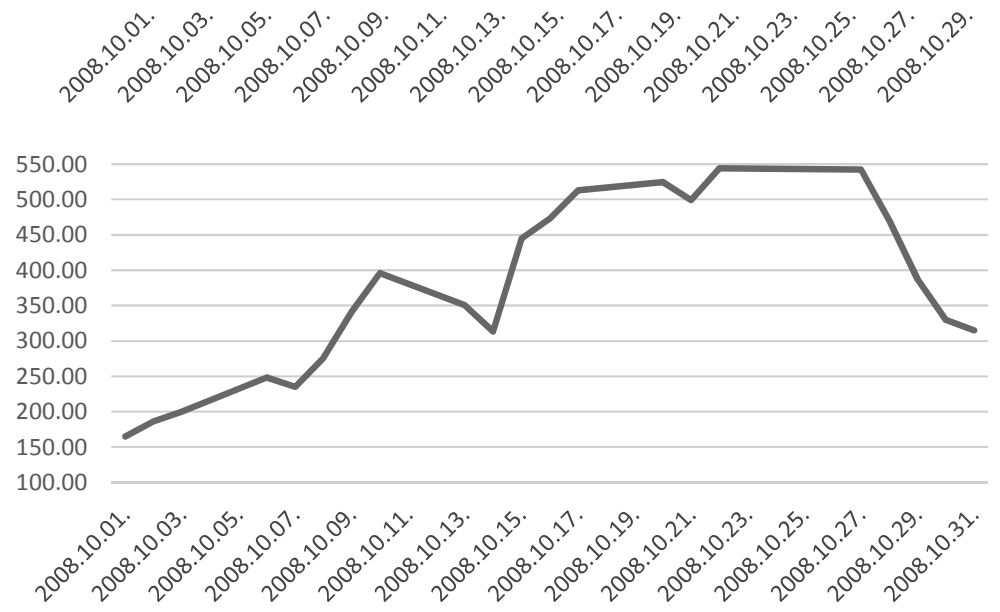

Figure 6. HUF/€ rate and the five-year CDS spread in October 2008

Source: Reuters.

strengthened economic policies, we expect that banks and other financial institutions operating in the country will continue to provide adequate financing." 19

On $27^{\text {th }}$ October (Monday), after the official announcement of the agreement, the newspaper headlines reflected the restored market confidence. The package was impressive and convincing: 12.5 billion $€$ from the IMF, 6.5 billion $€$ from the EU, and 1 billion $€$ from the World Bank, all in all a 20 billion $€$ stand-by loan. The interest rate of the loan was between 2-3 per cent (with a 25-35 basis points fee for commitment), much below the market rates, since the secondary market yield of the 10-year government bonds was oscillating around 10-13 per cent.

The acute stress period lasted from $9^{\text {th }}$ October till $27^{\text {th }}$ October. During this fortnight, the HUF/EUR ratio dropped from 250 to 275, while the CDS spread of the country increased from 235 to 544 basis points (Figure 6). During one month, 
1000 billion HUF (4 billion $€$ ) government bonds (one third of the total) were liquidated by foreign investors.

The IMF-EU deal and the other crisis prevention measures mentioned above had positive effect on the markets, and by the end of October the liquidity crisis was more or less over. Even the Economist admitted: "The Hungarian central bank is impressively well-run." ${ }^{20}$ It was only the first phase of the Great Financial Economic crisis, but the acute crisis period was over. The most difficult task: to overcome the credit crunch and the recession was still ahead of the country. However, the analysis of the recession would exceed the framework of the given paper.

\section{THE PIECES OF THE PUZZLE WERE PUT TOGETHER - CONCLUSION}

In November 2008, Her Majesty the Queen visited the London School of Economics and asked a trivial question: "if these things were so large, how come everyone missed them?". The short and sorrowful answer is: because it was impossible to foresee. Professors of the LSE explained this short answer in a long letter: ${ }^{21}$ "Many people did foresee the crisis. However, the exact form that it would take and the timing of its onset and ferocity were foreseen by nobody. What matters in such circumstances is not just to predict the nature of the problem but also its timing. And there is also finding the will to act and being sure that authorities have as part of their powers the right instruments to bring to bear on the problem... But the difficulty was seeing the risk to the system as a whole rather than to any specific financial instrument or loan" (Besley - Hennesy 2009). That is the same, what is said by Ben Bernanke: "Toward the end of my tenure as chairman, I was asked what had surprised me the most about the financial crisis. 'The crisis,' I said. I did not mean we missed entirely what was going on. We saw, albeit often imperfectly, most of the pieces of the puzzle. But we failed to understand - 'failed to imagine' might be a better phrase - how those pieces would fit together to produce a financial crisis that compared to, and arguably surpassed, the financial crisis that ushered in the Great Depression."

Several central bankers, including the Hungarians felt the same during the crisis. All the details were observed, but the "big picture" was, anyhow, lost. The strength and deepness of the crisis, the brutal sudden stop and then the credit crunch surprised all of us, who were part of the game.

20 http://www.economist.com/node/12465279 „Who is the next”, Economist, October 23, 2008.

21 „The Global Financial Crisis - Why Didn't Anybody Notice?” https://www.britac.ac.uk/ global-financial-crisis-why-didnt-anybody-notice 
Let's put together the individual pieces of the puzzle in case of Hungary! The staff of the central bank did it already a few weeks after the crisis, and could explain with the help of a simple block diagram what happened and why, how the pieces of the puzzle fitted together.

Though in 1995, the so called Bokros - Surányi consolidation ${ }^{22}$ package put the economy on a sustainable growth path (Kornai 1996; Antal 2001), from the beginning of the 2000s due to the irresponsible policy, the path was left. "Fiscal alcoholism" (Kopits 1998) characterized the fiscal policy, especially in the years of elections. The four-year fiscal cycles repeated from time to time, resulting in accelerating budget deficit and debt. Fiscal alcoholism generated the overheating of the economy; the increasing positive output gap put a permanent pressure on the inflation. As a responsible inflation targeter, the central bank tightened the monetary conditions, increased base rate attempting to build its own credibility.

High money market rates, inflationary pressure in HUF-terms and the liquidity awash on the international money markets made the FX denominated loans attractive both for the lenders and the borrowers. It caused the over-indebtedness of households, high leverage in banks ( $150 \%$ loan/deposit ratio) and a permanently increasing external indebtedness, in spite of the finally unfolding budget consolidation. In 2008, only one third of the country's net external debt was due to the government and two third belonged to the private sector. Banks were exposed for increasing foreign funding (deposit and swap), which started rapidly shorten after the outbreak of the subprime crisis that threatened the foreign reserves of the MNB. No matter that the reserves were in line with the Guidotti - Greenspan rule, analysts declared them insufficient, disregarding the mother banks' responsibility (Tooze 2018).

The puzzle, as it really looked like in 2008 , now can be easily put together: higher than in the neighbouring countries government debt (77.8 per cent of the GDP), over-indebtedness of households in FX (more than 70 per cent of total loans were denominated in FX), higher than in the neighbouring countries external debt (45\% net and 98\% gross debt of the GDP), and the lower than required foreign reserves - all contributed to the extreme vulnerability of Hungary (Figure 7).

The Lehman tsunami hit the country with full force, but the help of the IMF and the EU, the responsible behaviour of the foreign mother banks and the rapid crisis management of the MNB prevented Hungary to become the second Iceland.

22 In 1995, Mr. Lajos Bokros served as Minister of Finance, while Mr. György Surányi was Governor of MNB. 


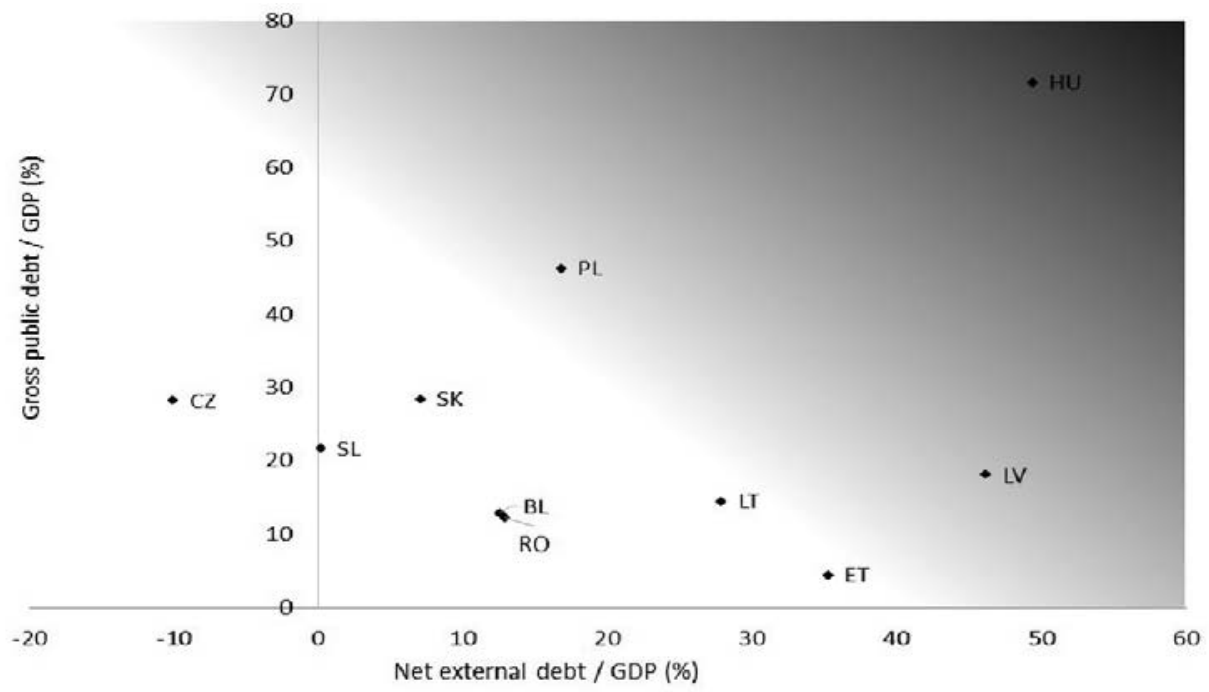

Figure 7. Gross public debt and net external debt as compared to GDP in CEE countries

Source: Eurostat.

\section{REFERENCES}

Antal, L. (2004): Fenntartható-e a fenntartható növekedés? Az átmeneti gazdaságok tapasztalatai (Can the Unsustainable Growth Path be Sustainable? Evidence from the Transition Economies). Budapest: Közgazdasági Szemle Alapítvány

Bernanke, B. (2007): The Subprime Mortgage Market. Presentation at the Federal Reserve Bank of Chicago's 43rd Annual Conference on Bank Structure and Competition, Chicago, Illinois, May 17, 2007. https://www.federalreserve.gov/newsevents/speech/bernanke20070517a.htm

Bernanke, B. (2015): The Courage to Act: A Memoir of a Crisis and Its Aftermath. W.W. Norton \& Company.

Besley, T. - Hennesy, P. (2009): The Global Financial Crisis - Why Didn't Anybody Notice? British Academy Review, 14: 8-10.

Blinder, A. S. (2013): After the Music Stopped. The Financial Crisis, the Response, and the Work Ahead. The Penguin Press.

Dooley, M. - Hutchison, M. (2009): Transmission of the U.S. Subprime Crisis to Emerging Markets: Evidence on the Decoupling - Recoupling Hypothesis. Journal of International Money and Finance, 28(8): 1331-1349.

ECB (2005): The (Un)Reliability of Output Gap Estimates in Real Time. ECB Monthly Bulletin, February 2005, Box 5: 43-45. https://www.ecb.europa.eu/pub/pdf/other/mb200502_focus 05 . en.pdf?cb1e42a54296e7dbc045d5dd64112655

Giorno, C. - Richardson, P. - Roseveare, D. - van den Noord, P. (1995): Estimating Potential Output, Output Gaps and Structural Budget Balances. Working Papers, No. 152, OECD Economics Department, Paris. http://dx.doi.org/10.1787/533876774515

Greenspan, A. (1999): Currency Reserves and Debt. Remarks by Chairman Alan Greenspan before the World Bank Conference on Recent Trends in Reserves Management, Washington, D.C., April 29, 1999. https://www.federalreserve.gov/BoardDocs/Speeches/1999/19990429.htm 
Kopits, Gy. (2008): Saving Hungary's Finances. Wall Street Journal, December 4, 2008.

Kornai, J. (1996): Paying the Bill for Goulash-Communism: Hungarian Development and Macro Stabilization in Political-Economy Perspective. Social Research, Winter, 63(4): 943-1040.

Mérö, K. (2017): The Emergence of Macroprudential Bank Regulation: A Review. Acta Oeconomica, 67(3): 289-309.

MC Press Releases and Minutes 2006-2008: http://www.mnb.hu/en/monetary-policy/the-monetary-council

MNB (2008): A devizatartalék megfelelő szintje. Az MNB válaszol (The Resuired Level of International Reserve. Reply of the MNB). Portfólió, November 19, 2008. https://www.portfolio.hu/ gazdasag/a-devizatartalek-megfelelo-szintje-az-mnb-valaszol.106233.html

Mueller, S. A. - Anderson, J. E. - Wallington, T. J. (2011): Impact of Biofuel Production and Other Supply and Demand Factors on Food Price Increases in 2008. Biomass and Bioenergy, 35(5): $1623-1632$.

Ongena,S. - Schindele, I. - Vonnák, D. (2017): In Lands of Foreign Currency Credit, Bank Lending Channels Run Through? MNB Working Papers, No. 6. https://www.mnb.hu/letoltes/mnb-wp2017-6-final-hu.pdf

Papadia, F. - Välimäki, T. (2018): Central Banking in Turbulent Times. Oxford University Press. Tooze, A. (2018): Crashed: How a Decade of Financial Crises Changed the World. Penguin. 